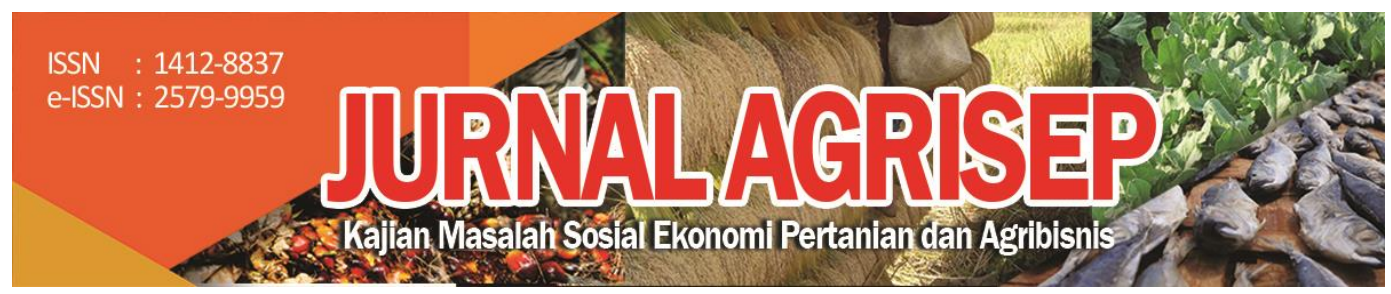

DOI: 10.31186/jagrisep.20.1.41-54

\title{
ANALISIS PERBANDINGAN KEUNGGULAN KOMPETITIF DAN KOMPARATIF USAHATANI KEDELAI DAN PADI DI KABUPATEN GROBOGAN
}

\section{The Comparison Analysis Of Competitive And Comparative Advantage Between Soybean And Rice Farming In Grobogan Regency}

\author{
Irvan Aji Saputra $\bigotimes_{1}$; ; Liska Simamora2); Yuliawati ${ }^{3)}$ \\ 1),2),3) Jurusan Agribisnis Fakultas Pertanian dan Bisnis Universitas Kristen \\ Satya Wacana \\ Email: 522016031@student.uksw.edu
}

\begin{abstract}
Grobogan District is a central of Soybeans and rice productions in Central Java. The purpose of this research is to know the value of a competitive, comparative, the financial and economic advantage of the soybeans and rice in Grobogan district. the study was conducted through by interviewing with 32 farms of soybeans and rice farmers as selected responders using purposive sampling techniques, namely farmers who planted soybeans and rice in the 2019/2020 planting season. The data analysis is used the Policy Analysis Matrix table (PAM). The result shows that both of the competitive and cooperative advantage of PCR result a pointed 0.30 and 0.28 with the $D R C R$ score 0.44 and 0.14 , the score is $<1$. Soybeans and rice farming in Grobogan district have a financial advantages around IDR 6.337.411/ha and IDR 14.713.109/ha, with ecomonic benefits of IDR 5.18.606/ha and IDR 33.698.996/ha.
\end{abstract}

Keywords: soybean, paddy, comparative advantage, competitive competitive

\section{ABSTRAK}

Kabupaten Grobogan merupakan sentra produksi kedelai dan padi di Jawa Tengah. Penelitian ini bertujuan untuk mengetahui nilai keunggulan kompetitif, keunggulan komparatif, keuntungan finansial dan keuntungan ekonomi dari usahatani kedelai dan padi di Kabupaten Grobogan. Penelitian ini dilakukan melalui kegiatan wawancara dengan masing-masing 32 petani kedelai dan padi sebagai responden yang dipilih melalui teknik purposive sampling, yaitu petani yang menanam kedelai dan padi 
musim tanam 2019/2020. Data dianalisis dengan menggunakan tabel Policy Analysis Matrix (PAM). Hasil Analisis menunjukkan jika Usahatani kedelai dan padi di Kabupaten Grobogan sama-sama memiliki keunggulan kompetitif dan komparatif terlihat dari hasil PCR yang menunjukkan nilai 0,30 dan 0,28, dengan nilai DRCR sebesar 0,44 dan 0,14 dimana nilai tersebut $<1$. Usahatani kedelai dan padi di Kabupaten Grobogan juga memiliki keuntungan finansial senilai Rp.6.337.411/ha dan Rp.14.713.109/ha, dengan nilai keuntungan ekonomi sebesar Rp.5.318.606/ha dan Rp.33.698.996/ha.

Kata Kunci: kedelai, padi, keunggulan komparatif, keunggulan kompetitif

\section{PENDAHULUAN}

Kedelai dan padi merupakan komoditas tanaman pangan dengan tingkat permintaan yang tinggi. Tingkat konsumsi masyarakat terhadap kedelai cenderung meningkat, sesuai dengan data Kementerian Pertanian (2018) menjelaskan jika konsumsi kedelai perkapita selama periode tahun (2002-2018) relatif meningkat $0,22 \%$ per tahun, dari konsumsi tahun 2002 sebesar 7.45 $\mathrm{kg} / \mathrm{kapita} /$ tahun hingga di tahun 2018 konsumsi kedelai nasional mencapai $7.51 \mathrm{~kg} / \mathrm{kapita} /$ tahun dengan pola konsumsi fluktuatif. Tingkat konsumsi masyarakat terhadap beras cenderung mengalami penurunan, pada periode tahun 2002-2018 konsumsi beras mengalami rata-rata penurunan sebesar 0,21\% dari tingkat konsumsi di tahun 2002 sebesar 107,7 kg/kapita/tahun cenderung menurun hingga di tahun 2018 menjadi $96.325 \mathrm{~kg} / \mathrm{kapita} / \mathrm{tahun}$.

Kabupaten Grobogan menjadi sentra produksi kedelai dan padi di Jawa Tengah dengan produktifitas kedelai di Kabupaten Grobogan mencapai 16,64 kuintal/ha, lebih tinggi jika dibandingkan dengan rata-rata tingkat produktifitas kedelai Jawa Tengah yaitu 15,84 kuintal/ha (BPS Jawa Tengah, 2018). Kabupaten Grobogan menjadi daerah dengan kontribusi kedelai tertinggi di Jawa Tengah, dengan kontribusi kedelai lebih dari 25\% dari produksi kedelai Jawa Tengah. Produktifitas padi di Kabupaten Grobogan yaitu sebesar 63,67 kuintal/ha, angka ini juga menunjukkan nilai yang lebih tinggi dibandingkan dengan rata-rata produktifitas padi di provinsi Jawa Tengah sebesar 60,99 kuintal/ha (BPS Jawa Tengah, 2015).

Kebutuhan konsumen terhadap kedelai dan padi perlu untuk dipenuhi baik pemenuhan yang diperoleh dari produksi dalam negeri maupun didukung dari produk impor. Perdagangan ekspor dan impor ini menjadikan adanya persaingan pasar, sehingga untuk dapat bersaing suatu produk harus memiliki nilai keunggulan kompetitif dan komparatif. Selain itu, usahatani yang dijalankan sudah seharusnya memberikan nilai keuntungan secara finansial maupun ekonomi. Belum banyaknya petani yang melakukan perhitungan antara biaya produksi dan pendapatan selama usahatani berjalan, mengakibatkan banyaknya petani yang belum mengetahui pasti tingkat 
keuntungan usahatani dan apakah usahatani yang dijalankan sudah berjalan secara efisien. Perbedaan tingkat produktifitas usahatani kedelai dengan usahatani padi menjadikan perlu adanya perbandingan untuk mengetahui usahatani yang lebih menguntungkan dan lebih efisien untuk diproduksi di dalam negeri.

Perbandingan tingkat keunggulan kompetitif dan komparatif antara usahatani kedelai dengan padi sebagai komoditas unggulan di Kabupaten Grobogan menjadi penting dilakukan untuk mengetahui seberapa efisien usahatani guna menentukan kebijakan pengembangan usahatani yang harus di prioritaskan, sehingga kebijakan dapat tepat sasaran dan memberikan keuntungkan bagi petani. Analisis dengan menggunakan tabel PAM dapat memberikan gambaran tentang tingkat keunggulan kompetitif maupun komparatif seperti penelitian-penelitian yang telah dilakukan oleh Firdaus, (2007) tentang analisis daya saing kedelai dan Haryono \& Kasymir, (2010) tentang keunggulan komparatif dan kompetitif.

Tujuan dari penelitian ini yaitu untuk mengetahui nilai keunggulan kompetitif maupun komparatif usahatani kedelai dan padi di Kabupaten Grobogan, selain itu penelitian ini juga untuk mengetahui keuntungan usahatani dari segi finansial dan ekonomi usahatani kedelai dan padi di Kabupaten Grobogan.

\section{METODE PENELITIAN}

Penelitian ini dilaksakan di Dusun Nanggungan, Desa Jatiharjo, Kabupaten Grobogan, Provinsi Jawa Tengah, pemilihan lokasi dilakukan secara sengaja dengan pertimbangan penetapan lokasi penelitian didasarkan pada tingkat produktivitas kedelai dan padi di Jawa Tengah. Penelitian ini menggunakan dua jenis data yaitu data primer dan data sekunder, yaitu data yang bersifat kuantitatif maupun data yang bersifat kualitatif.

Teknik pengambilan sampel dalam penelitian ini yaitu purposive sampling, yaitu petani yang menanam kedelai dan padi musim tanam 2019/2020 dan penentuan lokasi dengan Cluster Sampling yang didasarkan pada kelompok, kelompok subjek atau daerah yang berkumpul bersama, dalam penelitian ini didasarkan pada daerah dengan tingkat luas lahan dan produktifitas kedelai dan padi di Kabupaten Grobogan Singarimbun et al., (2017). Populasi dari petani kedelai dan padi di Dusun Nanggungan setidaknya yaitu sebanyak 324 petani kedelai dan petani padi, penentuan jumlah sampel menggunakan metode Gay \& Diehl, (1992), untuk penelitian deskriptif sampel yang digunakan yaitu $10 \%$ dari populasi, sehingga sampel yang dibutuhkan dalam penelitian ini yaitu sebanyak 32 petani kedelai dan 32 petani padi. Data di analisis dengan menggunakan metode Police Analysis Matrix (PAM), tabel PAM dapat menunjukkan tingkat keunggulan kompetitif 
dan komparatif usahatani serta nilai keuntungan baik segi finansial maupun ekonomi, ada dan tidaknya keunggulan kompetitif dan komparatif dapat diketahui dari hasil Privatee Cost Ratio (PCR) dan Domestic Resource Cost Ratio (DRCR). PCR yaitu perbandingan antara input tenaga kerja dan modal (input non tradable) dengan nilai tambah privat usahatani atau pendapatan dikurangi dengan biaya (pendapatan - input tradable), DRCR yaitu perbandingan antara input tenaga kerja dan modal (input non tradable) dengan nilai tambah privat usahatani atau pendapatan dikurangi dengan biaya (pendapatan - input tradable) dengan menggunakan biaya sosial atau harga internasional. Keuntungan finansial diperoleh dari hasil hasil pengurangan antara pendapatan dengan total biaya menggunakan harga yang benar-benar terjadi di lapangan, sedangkan nilai keuntungan ekonomi diperoleh dari hasil pengurangan antara pendapatan dengan total biaya menggunakan harga sosial atau harga internasional (Pearson et al., 2005).

Tabel 1. Tabel PAM Police Analysis Matrix (PAM)

\begin{tabular}{lcccc}
\hline & Pendapatan & \multicolumn{3}{c}{ Biaya Usahatani } \\
\cline { 3 - 5 } & & $\begin{array}{c}\text { Input } \\
\text { Tradable }\end{array}$ & $\begin{array}{c}\text { Input Non- } \\
\text { Tradable }\end{array}$ & Keuntungan \\
\hline Private Cost & $\mathrm{A}$ & $\mathrm{B}$ & $\mathrm{C}$ & $\mathrm{D}$ \\
Social Cost & $\mathrm{E}$ & $\mathrm{F}$ & $\mathrm{G}$ & $\mathrm{H}$ \\
Divergensi & $\mathrm{I}$ & $\mathrm{J}$ & $\mathrm{K}$ & $\mathrm{L}$ \\
\hline Sunyyyy
\end{tabular}

Sumber: Pearson (2005)

$\mathrm{PCR}=\mathrm{C} /(\mathrm{A}-\mathrm{B}) \quad$ Keuntungan Finansial $=\mathrm{A}-(\mathrm{B}+\mathrm{C})$

$\mathrm{DRCR}=\mathrm{G} /(\mathrm{E}-\mathrm{F}) \quad$ Keuntungan Ekonomi $=\mathrm{E}-(\mathrm{F}+\mathrm{G})$

\section{HASIL DAN PEMBAHASAN}

\section{Keunggulan Kompetitif Usahatani Kedelai dan Padi}

Perhitungan nilai keunggulan kompetitif pada tabel Police Analysis Matrix (PAM) menggunakan perhitungan Price Cost Ratio (PCR) yaitu perbandingan antara input tenaga kerja dan modal (input non tradable) dengan nilai tambah privat usahatani atau pendapatan dikurangi dengan biaya (pendapatan - input tradable). Dari hasil perhitungan dengan menggunakan tabel PAM, nilai PCR dari usahatani kedelai dan padi menunjukkan nilai < 1 yaitu 0,30 dan 0,28 seperti pada Tabel 1., nilai tersebut menunjukkan jika usahatani kedelai dan padi di Kabupaten Grobogan layak untuk dikembangkan, hasil dari PCR dapat dijelaskan jika untuk mendapatkan nilai tambah sebesar satu satuan, diperlukan tambahan biaya domestik kurang dari satu satuan, atau untuk dapat menghemat devisa sebesar satu-satuan diperlukan tambahan biaya domestik kurang dari satu satuan, semakin rendah nilai PCR dibawah angka satu maka usahatani kedelai

44 | Irvan Aji Saputra, Liska Simamora,' Yuliawati; Analisis Perbandingan... 
akan semakin efisien. Dari hasil tersebut maka usahatani kedelai dan padi di Kabupaten Grobogan Kecamatan Pulokulon memiliki keunggulan kompetitif.

Hingga saat ini, usahatani padi menjadi pilihan utama petani di Kabupaten Grobogan Kecamatan Pulokulon, terutama pada musim tanam satu (MT1) dan musim tanam ke dua (MT2), salah satu alasan usahatani padi masih menjadi pilihan utama yaitu tingkat produktivitas tanaman padi yang cenderung lebih tinggi dibandingkan komoditas lain seperti kedelai dan jagung, selain itu harga dari padi juga cenderung lebih stabil. Meskipun biaya untuk menjalankan usahatani padi lebih tinggi dibandingkan dengan kedelai, tetapi pendapatan yang diperoleh petani padi masih dapat menutupi seluruh biaya akibat dari produktifitas padi yang cukup tinggi hingga mencapai 6 ton/ha dengan rata-rata harga aktual padi $4.046 / \mathrm{kg}$, sehingga pendapatan yang diperoleh dari hasil usahatani padi lebih tinggi dari pendapatan usahatani kedelai. Harga padi di Kabupaten Grobogan sesuai dengan hasil penelitian Yanti et al., (2019) jika harga minimum padi agar lebih kompetitif terhadap kedelai yaitu Rp 3.425.

Tabel 2. Tabel PAM Usahatani Kedelai dan Padi

\begin{tabular}{|c|c|c|c|c|c|}
\hline \multirow[b]{2}{*}{$\begin{array}{l}\text { Usahatani } \\
\text { Kedelai }\end{array}$} & \multirow[b]{2}{*}{ Pendapatan } & \multicolumn{3}{|c|}{ Biaya Usahatani Kedelai } & \multirow{2}{*}{$\begin{array}{c}\text { PCR } \\
\text { dan } \\
\text { DRCR }\end{array}$} \\
\hline & & $\begin{array}{c}\text { Input } \\
\text { Tradable }\end{array}$ & $\begin{array}{c}\text { Input Non- } \\
\text { Tradable }\end{array}$ & Keuntungan & \\
\hline Priv & 20557 & 2.185 .898 & 2.772 .262 & 63374 & 0,30 \\
\hline & & 57 & 2.78 & & 0,66 \\
\hline & & 323.759 & -17.475 & & - \\
\hline \multirow[b]{2}{*}{$\begin{array}{l}\text { Usahatani } \\
\text { Padi }\end{array}$} & \multirow[b]{2}{*}{ Pendapatan } & \multicolumn{3}{|c|}{ Biaya Usahatani Padi } & PCR \\
\hline & & $\begin{array}{c}\text { Input } \\
\text { Tradable }\end{array}$ & $\begin{array}{c}\text { Input Non- } \\
\text { Tradable }\end{array}$ & Keur & $\begin{array}{c}\text { dan } \\
\text { DRCR }\end{array}$ \\
\hline Priva & & 3.897 .584 & 5.663 .593 & & 0,28 \\
\hline Soci & 5.6 & 7.302 .918 & 5.642 .086 & 33.6 & 0,14 \\
\hline Divergensi & -22.369 .714 & -3.405 .334 & 21.507 & -18.985 .887 & - \\
\hline
\end{tabular}

Sumber: Data Primer Diolah (2020)

\section{Keunggulan Komparatif Usahatani Kedelai dan Padi}

Perhitungan nilai keunggulan komparatif pada tabel Police Analysis Matrix (PAM) menggunakan perhitungan Domestic Resource Cost Ratio (DRCR) yaitu perbandingan antara input tenaga kerja dan modal (input non tradable) dengan nilai tambah privat usahatani atau pendapatan dikurangi dengan biaya (pendapatan input tradable) dengan menggunakan biaya sosial. Dari hasil analisis menggunakan tabel PAM, nilai DRCR usahatani menunjukkan angka < 1 yaitu 0,66 dan 0,14 seperti pada Tabel 1. Hasil tersebut dapat dijelaskan jika usahatani kedelai dan padi di Kabupaten Grobogan Kecamatan Pulokulon memiliki keunggulan komparatif, nilai DRCR yang menunjukkan nilai $<1$ juga 
dapat diartikan untuk dapat menghemat devisa sebesar satu satuan dibutuhkan biaya korbanan kurang dari satu satuan, hal ini sesuai dengan yang dijelaskan oleh Suyatno et al., (2014) jika perhitungan DRCR merupakan perhitungan devisa yang dapat dihemat atas penggunaan sumberdaya domestik yang di produksi dan diperdagangkan.

Hasil dari nilai DRCR ini dapat digunakan untuk menguatkan hasil penelitian-penelitian sebelumnya jika usahatani kedelai dan padi masih memiliki keunggulan komparatif, seperti pada penelitian dari Zakaria et al., (2016), daya saing kedelai menurut agroekosistem, menunjukkan nilai < 1 secara berurutan yaitu 0,68 ; 0,76; dan 0,80 pada penelitian Sukmaya et al., (2017), tentang analisis daya saing dan dampak kebijakan pemerintah menunjukkan nilai DRCR usahatani kedelai $>1$ yaitu 1,13. dan pada penelitian Haryono \& Kasymir (2010), menunjukkan nilai DRCR usahatani padi di Kabupaten Lampung sebesar 0,4368, sedangkan penelitian dari Bandrang et al., (2015), menunjukkan nilai DRCR usahatani padi di Kabupaten Tasikmalaya sebesar 0,031 .

Dari hasil penelitian-penelitian terdahulu, dapat diketahui jika usahatani kedelai dibeberapa wilayah di Indonesia memiliki nilai keunggulan komparatif dan beberapa wilayah lagi belum memiliki nilai keunggulan secara komparatif. Hal ini menunjukkan adanya suatu perbedaan kondisi pertanian antar wilayah di Indonesia, hasil-hasil penelitian ini dapat digunakan sebagai salah satu pertimbangan bagi pemerintah untuk mengembangkan usahatani kedelai, yaitu pada lokasi-lokasi sentra produksi kedelai khususnya yang memiliki potensi untuk dapat terus dikembangkan

\section{Perbandingan Keunggulan Kompetitif dan Komparatif Usahatani Kedelai dengan Padi}

Hasil analisis menunjukkan usahatani padi memiliki nilai keunggulan kompetitif dan komparatif lebih tinggi dibandingkan dengan usahatani kedelai ditunjukkan oleh nilai PCR dan DRCR yang lebih rendah dimana semakin rendah nilai PCR dan DRCR maka akan semakin efisien suatu usahatani. Nilai PCR dan DRCR dapat dipengaruhi oleh biaya domestik, pendapatan, dan biaya-biaya dari input tradable. Memperhatikan dari biaya domestik atau input non tradable, usahatani padi memiliki total biaya yang lebih tinggi jika dibandingkan dengan kedelai, bahkan biaya domestik padi dapat mencapai dua kali lipat lebih tinggi dari biaya domestik usahatani kedelai (gambar 1).

Dilihat dari segi biaya tradable, usahatani kedelai membutuhkan biaya input tradable yang lebih rendah dibandingkan dengan usahatani padi. Pendapatan yang diperoleh dari usahatani kedelai juga lebih rendah, faktor yang paling berpengaruh terhadap total pendapatan dari usahatani padi yaitu produktivitas. Total produktivitas padi lebih tinggi dibandingakan kedelai 
menjadikan angka pendapatan yang diterima petani padi lebih tinggi, hal ini akan berpengaruh terhadap nilai dari PCR dan DRCR dari suatu usahatani.

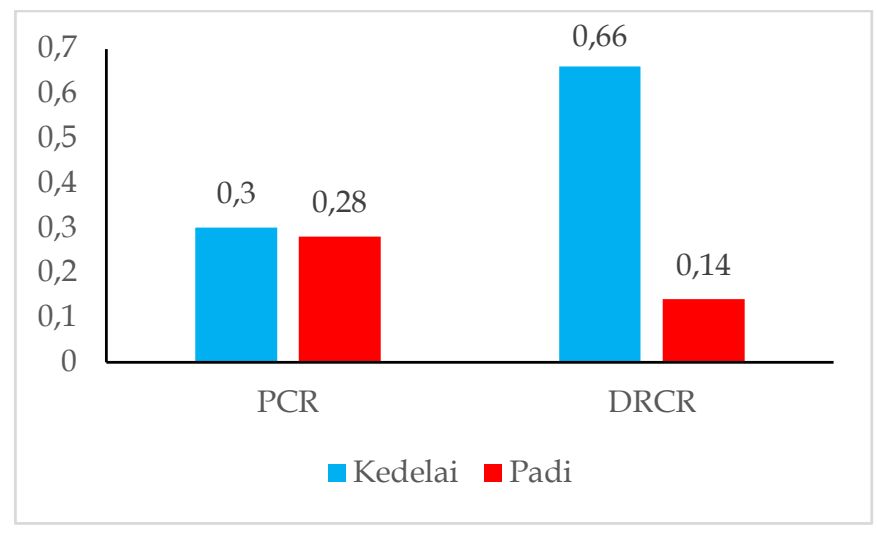

\section{Gambar 1. \\ Perbandingan Nilai PCR dan DRCR}

Secara keseluruhan dari keunggulan kompetitif dan keunggulan komparatif, usahatani padi masih lebih efisien dibandingkan dengan usahatani kedelai, hal ini dapat menjadi penyebab mengapa banyak petani yang lebih memprioritaskan komoditas tanaman padi daripada kedelai. Adapun hal yang perlu menjadi prioritas pengembangan adalah berkaitan dengan budidaya kedelai supaya dapat menghasilkan produktivitas kedelai yang tinggi seperti subsidi benih kedelai berkualitas baik, penyediaan pupuk dan obat-obatan yang tepat guna dan tepat waktu, serta pendampingan proses budidaya yang sesuai dengan kebutuhan tanaman kedelai. Peningkatan produktivitas juga dapat mendorong tingkat produksi kedelai dan padi nasional untuk memenuhi kebutuhan dalam negeri, sesuai dengan penelitian dari Kharisma, (2018) yang menyebutkan jika faktor yang dapat mempengaruhi produksi kedelai nasional salah satunya yaitu produktivitas. Adanya nilai keunggulan kompetitif dan komparatif, Yanti et al. (2019) menyebutkan jika komoditas tersebut lebih menguntungkan jika diproduksi di dalam negeri dibandingkan dengan impor produk yang sama.

Nilai Keunggulan Kompetitif dan Komparatif Usahatani kedelai dan Padi di Berbagai Wilayah Indonesia.

Kondisi pertanian di Indonesia memiliki berbagai perbedaan mulai dari kondisi lingkungan hingga teknologi yang digunakan dalam mendukung berjalannya kegiatan usahatani, perbedaan tersebut dapat berpengaruh terhadap kualitas dan kuantitas dari hasil panen, sehingga juga berpengaruh terhadap biaya yang dikeluarkan dan pendapatan yang diperoleh, adanya 
perbedaan biaya dan pendapatan dapat berpengaruh terhadap tingkat keunggulan kompetitif maupun komparatif dari usahatani.

Hasil penelitian usahatani kedelai dari Farid et al., (2009), menunjukkan jika usahatani kedelai yang dijalankan di Kabupaten Sumenep menunjukkan adanya nilai keunggulan kompetitif dan komparatif dilihat dari hasil PCR sebesar 0.30 dan DRCR sebesar 0.47. Penelitian lain dilakukan oleh Mutiara et al., (2013) menunjukkan nilai DRCR usahatani kedelai di Kabupaten Pasuruan sebesar 0.80. Penelitian lain yang dilakukan oleh Firdaus, (2007) tentang analisis daya saing kedelai di jawa timur menunjukkan nilai PCR untuk Kabupaten Jember dan Banyuwangi yaitu 0.87 dan 0,96 dengan nilai DRCR 0.94 dan 9.14, sementara itu usahatani kedelai di Kabupaten Lamongan justru tidak memiliki nilai keunggulan kompetitif dan komparatif terlihat dari nilai PCR sebesar 1.15 dan DRCR sebesar 1.13 (Sukmaya et al., 2017).

Usahatani padi di tiga Kabupaten yaitu Kabupaten Karawang, Kabupaten Kediri dan Kabupaten Sidrap, menunjukkan adanya keunggulan kompetitif dan komparatif dilihat dari nilai PCR secara berurutan yaitu 0.75, 0.85, dan 0.77 dengan nilai DRCR 0.93, 0.87, dan 0.77 (Rachman, 2011). Penelitian lain yang dilakukan oleh Widyatami \& Wiguna, (2019) menunjukkan nilai PCR dan DRCR usahatani padi di Kecamatan Rogojampi sebesar 0.67 dan 0,69 .

\section{Keuntungan Finansial Usahatani Kedelai dan Padi}

Keuntungan finansial merupakan selisih antara total penerimaan dengan total biaya yang dikeluarkan pada usahatani kedelai dan padi dihitung dengan menggunakan harga aktual atau harga yang benar-benar dikeluarkan oleh petani. Jenis biaya yang dikeluarkan meliputi biaya tradable dan non tradable, biaya tradable merupakan input biaya yang dapat diperjual belikan, sedangkan biaya non tradable merupakan input biaya yang tidak dapat diperjual belikan. Input tradable dalam penelitian ini meliputi biaya benih, pupuk, dan pestisida, sedangkan biaya non tradable meliputi biaya sewa lahan, tenaga kerja, pengelolaan air dan biaya-biaya lain yang tidak dapat diperjual belikan.

Dari hasil analisis dengan menggunakan tabel Policy Analysis Matrix (PAM), nilai keuntungan finansial dari usahatani kedelai sebesar Rp.6.337.411/ha, sedangkan nilai keuntungan finansial usahatani padi yaitu Rp.14.713.109/ha. Dari hasil tersebut dapat diketahui jika usahatani kedelai dan padi masih memberikan nilai keuntungan secara finansial dapat dilihat dari hasil perhitungan menunjukkan nilai $>1$. Adanya nilai keuntungan finansial menunjukkan usahatani yang dijalankan di Kabupaten Grobogan layak untuk dikembangkan disebabkan adanya pendapatan yang lebih tinggi dibandingkan dengan biaya yang dikeluarkan selama kegiatan usahatani berjalan, sehingga petani masih mendapatkan keuntungan bersih. 
Total biaya yang dikelurakan untuk menjalankan usahatani kedelai yaitu sebesar Rp.4.958.160/ha, dari biaya tradable sebesar Rp.2.185.898 dan biaya non tradable sebesar Rp.2.772.262. Total biaya yang dikeluarkan untuk menjalankan usahatani padi yaitu sebesar Rp.9.561.177/ha, dari biaya tradable sebesar Rp.3.897.584 dan biaya non tradable sebesar Rp.5.663.593. Dari total biaya privat atau biaya aktual yang dikeluarkan untuk usahatani kedelai, 39,21\% dikeluarkan untuk upah tenaga kerja, 16,20\% biaya benih, dan 15,62\% biaya pupuk, biaya-biaya lain dikeluarkan untuk pestisida, seleb dan biaya lain seperti pada Tabel 2. Dari total biaya privat yang dikeluarkan untuk usahatani padi, 49,05\% dikeluarkan untuk biaya upah tenaga kerja, 19,58\% biaya pupuk, 12,42\% biaya pestisida, dan biaya-biaya lain seperti pada Tabel 2.

Tabel 3. Biaya Privat Usahatani Kedelai dan Padi

\begin{tabular}{|c|c|c|c|c|}
\hline \multirow[b]{2}{*}{ Jenis Biaya Privat } & \multicolumn{2}{|c|}{ Usahatani Kedelai } & \multicolumn{2}{|c|}{ Usahatani Padi } \\
\hline & $\begin{array}{c}\text { Biaya/Ha } \\
\text { (Rp.) }\end{array}$ & $\begin{array}{c}\text { Persentase } \\
(\%)\end{array}$ & $\begin{array}{l}\text { Biaya/Ha } \\
\text { (Rp.) }\end{array}$ & $\begin{array}{c}\text { Persentase } \\
(\%)\end{array}$ \\
\hline Biaya Benih & 803.121 & 16,20 & 838.050 & 8,77 \\
\hline \multicolumn{5}{|l|}{ Input Tradable } \\
\hline Urea & 163.223 & 3,29 & 837,455 & 8,76 \\
\hline ZA & - & - & 36.696 & 0,38 \\
\hline NPK & 403.608 & 8,14 & 697.659 & 7,30 \\
\hline SP36 & 132.119 & 2,66 & 292.684 & 3,06 \\
\hline Organik & - & & 1.143 & 0,01 \\
\hline Pupuk Lain & 75.592 & 1,52 & 6.122 & 0,06 \\
\hline Insektisida & 526.739 & 10,62 & 853.358 & 8,93 \\
\hline Herbisida & 81.497 & 1,64 & 210.725 & 2,20 \\
\hline Fungisida & - & - & 123.692 & 1,29 \\
\hline \multirow{2}{*}{\multicolumn{5}{|c|}{$\begin{array}{l}\text { Input Non- } \\
\text { Tradable }\end{array}$}} \\
\hline & & & & \\
\hline Kelola Air & - & - & - & - \\
\hline Tenaga Kerja & 1.943 .982 & 39,21 & 4.689 .586 & 49,05 \\
\hline Sewa lahan & 447.510 & 9,03 & 158.667 & 1,66 \\
\hline Input Non-tradable & & & 815.341 & 8,53 \\
\hline lain & 380.771 & 7,68 & & \\
\hline Total Biaya & 4.958 .161 & 100 & 9.561.177 & 100 \\
\hline
\end{tabular}

Sumber: Data Primer Diolah (2020)

\section{Keuntungan Ekonomi Usahatani Kedelai dan Padi}

Keuntungan ekonomi merupakan selisih antara total pendapatan dengan total biaya usahatani yang dihitung dengan menggunakan harga sosial atau harga internasional. Pendapatan merupakan penerimaan yang diterima dari 
hasil penjualan barang, dalam hal ini meliputi penjualan kedelai dan padi, sedangkan total biaya merupakan biaya-biaya yang dikeluarkan selama usahatani berjalan meliputi biaya tradable atau biaya yang dapat diperjual belikan seperti benih, pupuk, dan pestisida, dan biaya non tradable atau biaya yang tidak dapat diperjual belikan seperti pengelolaan air, upah tenaga kerja, dan sewa lahan. Biaya sosial merupakan biaya internasional yang diperoleh dari hasil penjumlahan antara harga barang free on board (FOB) dengan biaya pajak, asuransi dan biaya penanganan lain.

Hasil analisis dengan menggunakan tabel Policy Analysis Matrix (PAM) menunjukkan hasil keuntungan ekonomi usahatani kedelai sebesar Rp.5.318.606/ha, dan keuntungan ekonomi usahatani padi sebesar Rp.33.698.996/ha. Dari hasil tersebut usahatani kedelai dan padi di Kabupaten Grobogan, Kecamatan Pulokulon masih memberikan keuntungan secara ekonomi dilihat dari hasil perhitungan yang menunjukkan nilai $>1$.

Total biaya dari usahatani kedelai dan padi selama satu musim tanam yaitu sebesar Rp.6.299.349 dan Rp.12.945.005 dihitung dengan menggunakan biaya sosial. Biaya usahatani kedelai dengan menggunakan harga sosial, $55,71 \%$ dipengaruhi oleh input tradable dan 44,29 input non tradable, sedangkan biaya usahatani padi $56,41 \%$ dipengaruhi oleh input tradable dan $43,59 \%$ dipengaruhi oleh input non tradable. Input yang berpengaruh dalam biaya usahatani kedelai yaitu upah tenaga kerja dengan persentase $29,96 \%$ dari total biaya, pupuk NPK, 17,77\%, dan benih 13,59\%, sedangkan input yang berpengaruh dalam biaya usahatani padi yaitu upah tenaga kerja dengan $35,30 \%$ dari total input, pupuk urea $16,14 \%$, dan pupuk NPK, $15,81 \%$.

\section{Perbandingan Keuntungan Finansial dan Keuntungan Ekonomi Usahatani Kedelai Dengan Padi}

Usahatani kedelai dan padi merupakan dua komoditas unggulan bidang pertanian di Kabupaten Grobogan, dua komoditas tersebut memiliki tingkat produktivitas, harga, dan biaya yang berbeda, sehingga perbandingan tingkat keuntungan finansial dan ekonomi antara usahatani kedelai dengan padi dapat digunakan sebagai sumber informasi tentang usahatani mana yang lebih menguntungkan dihitung dengan menggunakan biaya privat atau biaya aktual yang ada di lokasi penelitian untuk mengetahui tingat keuntungan finansial, dan dihitung dengan menggunakan biaya sosial atau biaya internasional untuk mengetahui tingkat keuntungan secara ekonomi.

Selisih pendapatan privat antara usahatani kedelai dengan padi yaitu Rp.12.978.715, diperoleh dari pengurangan pendapatan padi Rp.24.274.286 dengan pendapatan kedelai senilai Rp.11.295.571. Tingginya tingkat pendapatan dari usahatani padi dibandingkan dengan kedelai salah satu diantaranya dipengaruhi oleh produktivitas dari tanaman itu sendiri, padi 
memiliki tingkat produktivitas 3.24 kali lebih tinggi jika dibandingkan dengan kedelai.

Dilihat dari segi harga privat/aktual, kedelai memiliki rata-rata harga yang lebih tinggi dibandingkan dengan padi (Gambar 2), tetapi hal tersebut belum dapat membantu meningkatkan pendapatan untuk dapat melebihi tingkat pendapatan dari usahatani padi. Salain itu dari hasil perhitungan dengan harga internasional, pendapatan padi juga lebih tinggi dibandingkan dengan usahatani kedelai, selisih diantara usahatani kedelai dengan padi yaitu Rp.35.026.000/Ha, perbedaan ini selain disebabkan oleh tingkat produktivitas, juga dipengaruhi oleh harga internasional padi yang justru lebih tinggi dibandingkan dengan kedelai.

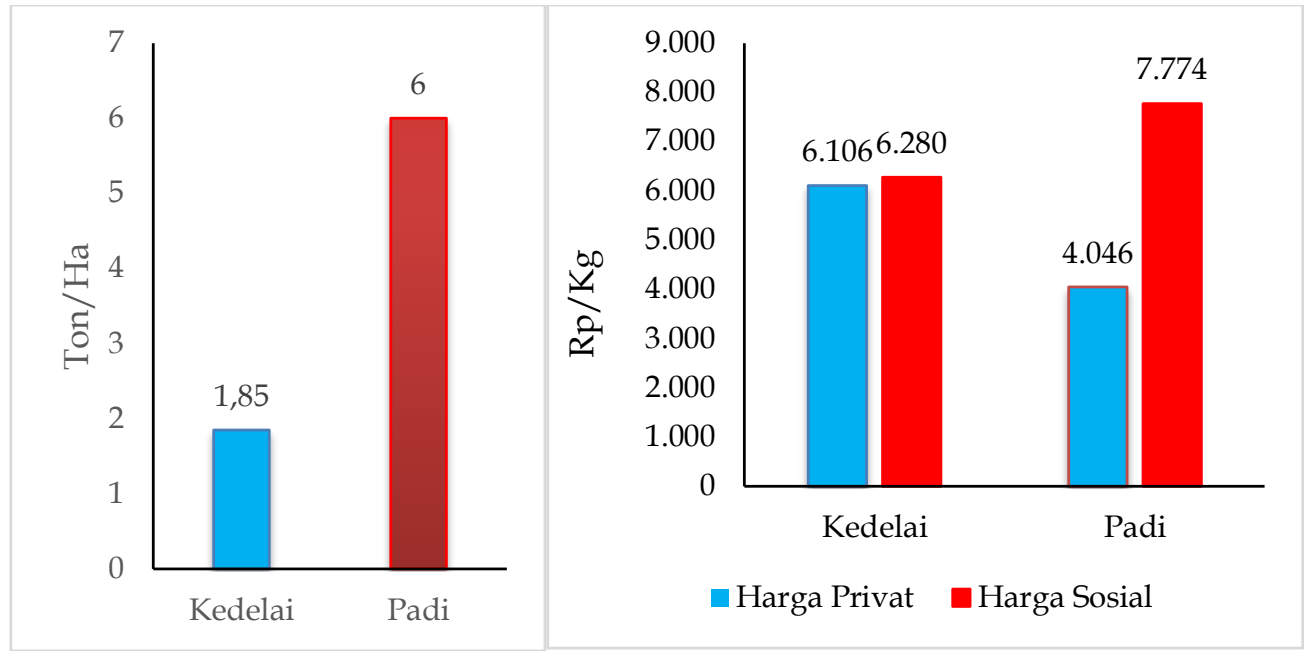

(a) Produktivitas

(b) Harga

Gambar 2.

Produktivitas dan Harga (Kedelai dan Padi)

Dapat diketahui jika usahatani padi memiliki nilai keuntungan baik secara finansial dan ekonomi yang lebih tinggi dibandingkan dengan usahatani kedelai seperti pada Gambar 3. Namun, sejalan dengan itu biaya yang dikeluarkan untuk pengelolaan usahatani padi juga lebih tinggi jika dibandingkan dengan usahatani kedelai. Hal ini dapat digunakan untuk menentukan komoditas unggulan yang dapat di tanam oleh petani dengan tetap menyesuaikan dengan kondisi lingkungan, cuaca, dan teknologi yang dimiliki, sehingga petani memperoleh nilai keuntungan yang lebih tinggi. Halhal yang perlu diperhatikan untuk dapat mengembangkan usaha pertanian di bidang ekonomi yaitu dengan penelitian-penelitian lanjutan untuk dapat meningkatkan produktivitas dari kedelai lokal, sehingga diharapkan dapat meningkatkan nilai keuntungan petani. Adapun penelitian terdahulu yang dilakukan oleh Nurhadi, (2010) menjelaskan jika tingkat produksi kedelai 
dapat dipengaruhi oleh benih, luas lahan, pupuk organik, pupuk kimia, insektisida dan tenaga kerja dapat dijadikan sebagai acuan pengembangan usahatani kedelai, serta perlu adanya perlindungan harga bagi hasil pertanian padi sehingga secara finansial usahatani padi juga mampu bersaing dan memberikan nilai keuntungan lebih bagi petani lokal.

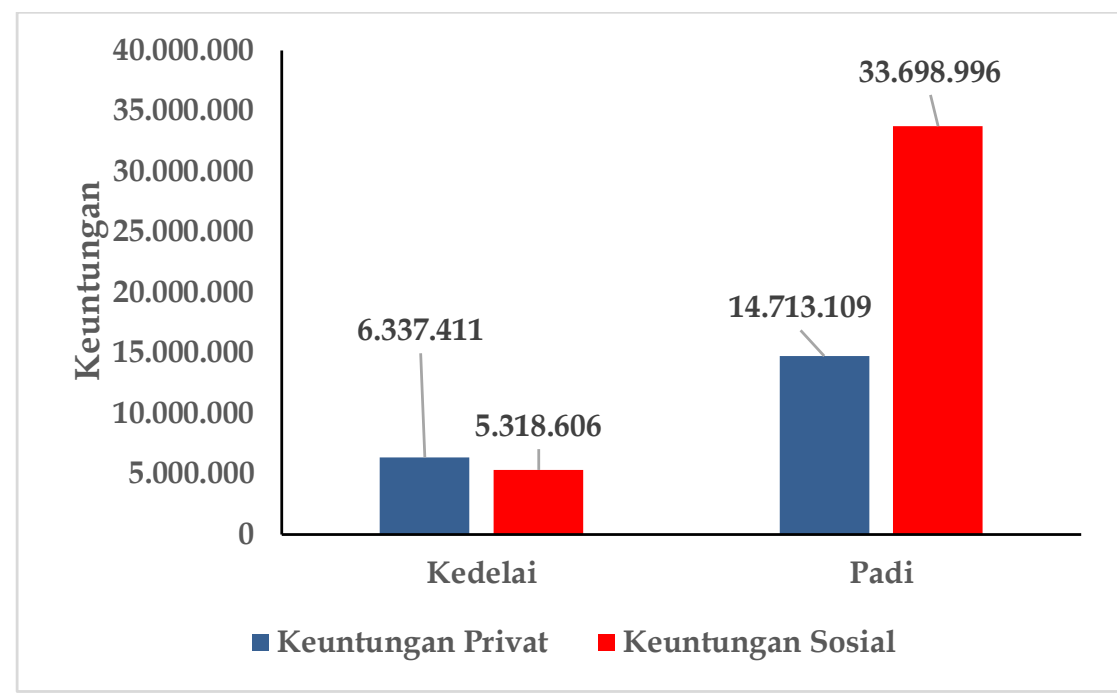

Gambar 3.

Keuntungan Finansial dan Keuntungan Ekonomi

\section{SIMPULAN DAN SARAN}

\section{Simpulan}

Usahatani kedelai dan padi di Kabupaten Grobogan sama-sama memiliki keunggulan kompetitif dan komparatif dilihat dari hasil PCR dan DRC usahatani yang menunjukkan nilai $<1$. Nilai PCR usahatani kedelai dan padi yaitu 0,30 dan 0,28 , dengan nilai DRCR sebesar 0,44 dan 0,14. Usahatani kedelai dan padi di Kabupaten Grobogan juga memberikan keuntungan secara finansial dan ekonomi terlihat dari hasil analisis yang menunjukkan nilai $>1$. Keuntungan finansial yang diperoleh dari usahatani kedelai dan padi dalam satu musim tanam yaitu Rp.6.337.411/ha dan Rp.14.713.109/ha, dengan nilai keuntungan ekonomi sebesar Rp.5.318.606/ha dan Rp.33.698.996/ha.

\section{Saran}

Pemerintah pusat maupun daerah perlu memberikan perlindungan terhadap harga jual kedelai dan padi di tingkat petani, sehingga harga jual kedelai dan padi secara aktual dapat bersaing dengan harga sosial pada jenis produk yang sama.

52 | Irvan Aji Saputra, Liska Simamora,' Yuliawati; Analisis Perbandingan... 
Pemerintah pusat maupun daerah perlu melakukan pengembangan terhadap teknologi pertanian seperti benih unggul, pupuk, pestisida, dan pembimbingan proses budidaya sehingga pengaplikasian dari teknologi baru dapat tepat guna, tepat waktu, dan tepat sasaran guna peningkatan produktivitas tanaman kedelai khususnya.

\section{DAFTAR PUSTAKA}

Bandrang, T. N., Natawidjaja, R. S., \& Karmana, M. 2015. Analisis Daya Saing dan Dampak Kebijakan Terhadap Beras Organik Ekspor ( Suatu Kasus di Gapoktan Simpatik Kabupaten Tasikmalaya ). Jurnal Ilmu Pertanian dan Peternakan

33-46. http://www.jurnal.unma.ac.id/index.php/AG/article/view File/388/367. BPS Jawa Tengah. 2015. Luas Panen, Produksi, dan Produktivitas Padi Sawah dan Padi Ladang Menurut Kabupaten/Kota di Provinsi Jawa Tengah, 2015. https://jateng.bps.go.id/statictable/2016/08/22/1311/luas-panenproduksi-dan-produktivitas-padi-sawah-dan-padi-ladang- menurutkabupaten-kota-di-provinsi-jawa-tengah-2015.html

BPS Jawa Tengah. 2018. Luas Panen, Produksi dan Produktifitas Kedelai Menurut Kabupaten/Kota Di Provinsi Jawa Tengah. https://jateng.bps.go.id/statictable/2019/10/15/1737/luas-panenproduksi-dan-produktivitas-kedelai-menurut-kabupaten-kota-diprovinsi-jawa-tengah-2018.html

Farid, M., Ekawati, I., \& Fatmawati, I. (2009). Analisis daya saing kedelai di kabupaten sumenep. CEMARA, 6, 24-34.

Firdaus, M. 2007. Analisis daya saing kedelai di jawa timur. Sosial Ekonomi Pertanian, 1(2), 16-27. https://jurnal.unej.ac.id/index.php/JSEP/article /view/450/307. 27 Desember 2019

Gay, L. R., \& Diehl, P. L. 1992. Research Methods For Business And Management. Maxwell Macmillan International.

Hardiyanto, T., \& Pardani, C. (2017). Analisis Keunggulan Kompetitif Beberapa Tanaman Pangan Utama Di Kabupaten Ciamis. MIMBAR AGRIBISNIS: Jurnal Pemikiran Masyarakat Ilmiah Berwawasan Agribisnis, 3(1), 73. https://doi.org/10.25157/ma.v3i1.77

Haryono, Z. D., \& Kasymir, E. 2010. Keunggulan Komparatif dan Kompetitif dalam Produksi Padi di Kabupaten Lampung Tengah Propinsi Lampung. $10(3)$,

185-199. https://doi.org/http://dx.doi.org/10.25181/jppt.v10i3.262.

Kementerian Pertanian. 2018. Pusat Data dan Sistem Informasi Pertanian Sekretariat Jenderal Kementerian Pertanian. In Buletin Konsumsi Pangan 09 ( $01):$ 32-42). 
http://epublikasi.setjen.pertanian.go.id/download/file/472-buletinkonsumsi-vol-10-no-1-2019

Kharisma, B. 2018. Determinan Produksi Kedelai di Indonesia dan Implikasi Kebijakannya. E-Jurnal Ekonomi Dan Bisnis Universitas Udayana, 3, 679.

Mutiara, F., Koestiono, D., \& Muhaimin, A. W. (2013). Keunggulan Komparatif dan Dampak Kebijakan Subsidi Input Output Terhadap Pengembangan Komoditas Kedelai (Glycine max) di Kabupaten Pasuruan. Habitat, XIV(2), 92-102.

Nurhadi, E. 2010. Daya Saing Usahatani Kedelai di Desa Wonokalang Kabupaten Sidoarjo. J-SEP, 4(1), 38-47.

Pearson, S., Gotsch, C., \& Bahri, S. 2005. Aplikasi Policy Analysis Matrix Pada Pertanian Indonesia (Pertama). Yayasan Obor Indonesia.

Rachman, B. 2011. Analisis Performa Dayasaing Komoditas Padi. Jurnal Penelitian Pertanian Terapan, 11(2), 84-91.

Singarimbun, M., Mantra, I. B., Effendi, S., Ancok, D., Manning, C., Kasto, Hagul, P., Singarimbun, I., Sucipto, T., Ismulyana, \& Tukiran. 2017. Metode Penelitian Survei. Penerbit LP3ES.

Sukmaya, S. G., Rachmina, D., \& Saptana, S. 2017. Analisis Daya Saing Dan Dampak Kebijakan Pemerintah Terhadap Komoditas Kedelai Vs Pengusahaan Kedelai Di Kabupaten Lamongan, Jawa Timur. Forum Agribisnis, 6(1), 2152. https://doi.org/10.29244/fagb.6.1.21-52.

Suyatno, A., Masyhuri, Mulyo, J. H., \& Irham. 2014. Keunggulan Komparatif Usahatani Padi Pada Berbagai Pola Agroekosistem di Kabupaten Mempawah. Jurnal Social Economic of Agriculture, 3(2), 1-11.

Widyatami, L. E., \& Wiguna, A. A. 2019. Daya Saing dan Dampak Kebijakan Pemerintah terhadap Usahatani Padi SRI di Kecamatan Rogojampi Kabupaten Banyuwangi. AGRARIS, 5(2), 100-111.

Yanti, M., Tarumun, S., \& Elinur. 2019. Keunggulan Kompetitif dan Keuntungan Usahatani Padi di Kota Dumai. Jurnal Agribisnis, 21, $142-149$.

Zakaria, A. K., Sejati, W. K., \& Kustiari, R. 2016. Analisis Daya Saing Komoditas Kedelai Menurut Agro Ekosistem: Kasus di Tiga Provinsi di Indonesia. Jurnal Agro Ekonomi, 28(1), 21. https://doi.org/10.21082/jae.v28n1.2010.21-37

54 | Irvan Aji Saputra, Liska Simamora,' Yuliawati; Analisis Perbandingan... 